\title{
The Concept of the Servant of God and Isaiah's Connection: A Politico-Theological Response to Recession
}

\author{
Dominic C. Obielosi \\ http://dx.doi./org/10.4314/ujah.v18i1.4
}

\section{Abstract}

To say that Nigeria is yet to be met with great and good news of feats and development since after independence is not an exaggeration. The true face is that the little the colonial masters did before they handed over is what we have enjoyed. Now most of them have dilapidated. There is no sign of a better future. One wonders what happened to Nigerian Telecommunications. There was a time we have phone boots on the streets. With a coin one can conveniently make calls. Fax machines were available in offices for private and public use. One can even send a telegram. To say that GSM and internet replaced them is an escapist manoeuvre. Think of Lagos Main Land Bridges, Niger Bridge, trains etc. People attribute the cause to corruption. The leaders are singled out as corrupt. But who are the leaders? People tend to limit their searchlight to the President, Senators and Governors. Evidently, they are not the managers of parastatals. They are not the law enforcement agencies etc. Yet, the truth is still obvious that a good leader can always push his subjects to a set vision and mission. What Nigeria needs is a servant leader. This paper is structured to examine in the main, the concept of the Servant of God, a servant leader as envisioned by Prophet Isaiah in what is popularly known as the Servant Songs. It is the belief of the researcher that a leader of such calibre is what Nigeria needs even in her recession to move forward. 


\section{Introduction}

The word \pm bd (עבד) is used twenty times in Deutero-Isaiah (DI). Already in First Isaiah (Isa 1-39), we meet the word five times in the singular and four times in the plural. But it has no affinity to that in DI. In Trito-Isaiah (Isa 56-66), it is used eleven times. All are in the plural; (cf. Isa 56,6; 63,17; 65,8.9.13 [3x].14.15; 66,14). This is in contrast to what we have in the DI where it occurs only in singular. In one of these occasions, it refers to the prophet Isaiah (Isa 44,26). In other eleven occasions, it refers to Jacob/Israel outside the Servant Songs; (cf. Isa 41,8-9; 42,19 [2x]; 43,10; $44,1.2 .21$ [2x]; 45,4; 48,20). On the other eight occasions, it makes reference to the figure of the Suffering Servant; (cf. Isa 42,1; $49,3.5 .6 .7 ; 50,10 ; 52,13 ; 53,11)$. Eight (8) of the occurrences in the DI are found in the Servant Songs (SS). The chapters containing the SS can be classified into two: Isa 40-48 or "hymns of Yahweh and Israel" and Isa 49-55 or "hymns of Jerusalem and Zion" (Mckenzie, 1965).

DI, embedded in his contemporary historical situation forms a synthesis of prophetic belief up to his time. It brings into one the Jewish belief in creation, divine intervention and government in history, and God's will to save. In a most pronounced way, he pictures Israel as an actor in this scene of God's eternal purpose. Israel is God's unique servant. This is the position of communal interpretation of the Suffering Servant. We also have individual and Christian interpretations. We do not intend to go into their respective argumentative disparities here. The respective views are given attention as they come up in the course of our discussions. She is a servant through whom a new thing is produced. This new thing is God-in-Israel. It is the last revealed. He undergoes a vicarious suffering. In this way, God Himself becomes the sin offering (Isa 53,10). According to Knight 
(1965) his suffering is remedial for all of mankind. In DI, the theme of the Servant of God (SG) narrows down in progression. It moves from Israel (Isa 41,8; 49,3) to one man Cyrus and then to a future Messiah-Servant (Isa 52,13). Israel waits in expectation for the advent of this Messiah. He is to be the saviour. He is to redeem not only Israel but all nations of the world. He is called to be a light to the nations. He is to gather all back to God (Isa 49,5-6). He willingly dies bearing the sins of others (Isa 53,4-9), though he is himself sinless (Isa 53,9). Again, he lives to administer the salvation he has won for them (Isa 53,10-12). It is this idea that captivated most New Testament (NT) authors. Put in pari-passu with Jesus, almost all NT writers depict Jesus as this SG. He is presented as having all the qualities of Isaiah's SG.

This paper gives the historical, theological and literary setting of the entire chapters of Isaiah's SS as reflected in the DI. Opinions vary as to the authorship of the SS. Disparity of views also exists among scholars as to the connection of the SS with the rest of DI. Even the identity of this Servant has remained a matter of unending debate. This is not unconnected with apparent ambiguity in Isaiah's presentation in both DI and in the SS. Scholars in the Jewish camp propose a Jewish interpretation. Admirers of the NT especially Acts 8,27-39 and 1Pet 2,22-25 settle for a Christian interpretation. Even among these, we still encounter divisions among those who uphold collective meaning and other proponents of historical individual theories. It is also factual that many still insist on an historico-messianic understanding, autobiography and even propose mythological theories. From the $18^{\text {th }}$ century, some scholars vouch for a messianic interpretation. Since the argument of our thesis is that John sees Isaiah's teaching as a prophecy in the state of coming to be and actualized in Jesus of Nazareth, it will be unnecessary to delve into all these 
controversial arguments. North (1966) provides well-articulated argument on all these positions.

\section{The Historico-literary Background, Message and Concept of Isaiah's SG Theme}

Every prophecy is about and to a people. Every prophecy grows from a cultural background. The shaping and even the content are not without connection with the political and socio-religious situation of the period of the prophecy. The same is true of DI. One is not able to fully grasp the message of DI in isolation from the socio-political setting of the prophecies. In this section, we have chosen to discuss in brief the Sitz-im-Leben and literary facts that shaped the structuring of Isaiah's teachings. It will also look into the theological context. A cursory look at the term 'Servant' as understood in antiquity and SG as a concept especially reflected in DI is also covered in this section, especially as it gives clarification and meaning to our exercise.

\section{Historical Background}

Isaiah's time spans the era of two world powers, first Assyria and then Babylonia. He prophesied in the time of Uzziah, Jotham, Ahaz and Hezekiah. All these exercised regal power over Judah (Isa 1,1; Koole, 1998). He was involved in active ministry for well over 40 years from 739 B.C., the year that Uzziah died (Isa 6,1) to after 701 B.C, the year that Sennacherib invaded Judah (Isa 36,1; Martin-Martin, 1983). Most probably Isaiah was still alive in 681 B.C. since he was able to record the death of Sennacherib (Isa 36,1). This means that he lived into the time of Manasseh. Thus his ministry both began and extended into the time of political, military and economic boom for both Judah and Israel (2Kgs $14,25.28$; $2 \mathrm{Chr} 26$ ), a national resurgence that led to self- 
confidence and self-indulgence resulted in injustices, oppressions, foreign alliances and religious hypocrisy denounced by Isaiah and led to his prophesying about the conquest of Israel by Assyria (Isa 28,1-13). Already in Isa 10,5-15, Isaiah the prophet described Assyria as a rod with which Yahweh would chastise his people and Judah by Babylon as divine punishment for their infidelity (Isa 39,1-8). This prophecy forms the bulk of the message of Isa 1-39. The language of the prophecy depicts the culture of the $8^{\text {th }}$ century Jerusalem. North (1966) is of the opinion that though Isaiah could have written his prophecy in this period, it must be interpreted against the background of $6^{\text {th }}$ century B.C. because of the time of the actualization of the events described. The point made by North, good as it sounds, is not all the truth. Parts of the book unmistakably presuppose the $8^{\text {th }}$ century B.C. as the period in which it is written. For instance, Isa 9,7-10,14 presupposes the existence of the Northern Kingdom which came to an end in 722 B.C. This section of Isaiah also predicts its fall. DI 40-55, presupposes the period of Babylonian exile which began in 587 (586) B.C. It predicts the imminent fall of Babylon through Cyrus' invasion which actually happened in 538 B.C. Thus Gray (1912) observes three moments in the compilation of the book of Isaiah:

i. $\quad$ Prophecies of the $8^{\text {th }}$ century B.C.

ii. Prophecies of the $6^{\text {th }}$ century B.C. or later.

iii. The work of an editor who compiled together these prophecies.

It is replete with messages of hope lost. God punished his people. The Holy Place was broken into and defiled. Both the king and the inhabitants of Judah and Israel suffered the fate of exile under Babylon and Assyria respectively. It was a period of darkness for the uninformed. For Isaiah, it is not the end. It is rather a purgation. It is the constant teaching of Isaiah that the 
ultimate purpose of God's judgement on Israel was to purify and to restore the nation. Production of righteousness and justice is the intent (cf. Isa 1,$26 ; 4,4 ; 32,15-20 ; 40,2$ ). It is meant to be a purgation of idolatry Isa 30,$22 ; 31,7$ ) and a re-establishment of faith (Isa 10,20). All these are for His glory (Isa 2,11.17). Apart from Israel, the world is to be judged and punished too for its evil and rebellion against God (Isa 13,11). This includes Assyria (Isa 10,5-19; 37,22-38), Babylon (Isa 13,19; 47,1-15), Moab (Isa 15,1$16,14 ; 25,10-12)$, Tyre (23,1-9) and Egypt (Isa 19,1-25). In all these, the primary purpose is God's glorification of Himself (Isa 33,10; 45,6; 66,18-19). God is the ultimate Judge (Isa 63,1-6), but He uses various instruments: Babylon and Assyria were used to judge Israel, Cyrus (Isa 41,25; 45,1-13), the Davidic Messiah (Isa 11,4 ) together with Israel (Isa 11,$14 ; 19,17 ; 41,14-16$ ) to judge the nations. God is ever faithful and can never fail. Hope is not lost. First Isaiah is a period of judgement for sins. Deutero-Isaiah has another message. The message is both for Israel and the world.

DI proposes a message of consolation. The Babylonian destruction of Judah in 586 B.C. and the period proximate to the end of the Babylonian exile in 538 B.C. are evidently the background of DI. It is noteworthy that DI is assigned to a different author. According to Morgenstern (1961), scholars are in agreement in this attribution. The reasons for this are traceable to the historical, doctrinal and literary backgrounds. Isa 44,28 and 45,1 mention Cyrus, the Persian King by name as both a threat to Babylon and a liberator of Israel. Most probably, therefore, DI dates back to between 550-540 B.C. while Isa 1-39 are addressed to Judah, Israel and the Gentile nations in the $8^{\text {th }}$ century B.C. Doctrinally, Second Isaiah gives an explicit formulation of monotheism and messianic deliverance. These thoughts are not clear in First Isaiah (Isa 1-39). Mckenzie (1965) says that over and 
above the literary style of First Isaiah (FI), Deutero-Isaiah is distinctive and powerful. This notwithstanding, it is possible that the author is also Isaiah by name. Like John, James and Jesus, the name Isaiah was a common parlance in the OT. Cf. 1Chr 25,3.15; Ezra 8,7; Neh 11,7. It is not within the purview of our work to dwell in depth on the unity of the book of Isaiah. For further information on this see Harrison (1969); Archer Jr. (1964), Eissfeldt (1965). Knight(1965) is of the opinion that Isaiah made some proclamations about the plan of God that was yet to be worked out in Israel's life and experience. DI proceeds to demonstrate how that plan is being realized in his own day. He goes on to declare that it will continue to unfold in Israel's life in the days to follow. It envisages the Babylonian exile (Motyer, 1999).

Knight (1965) observes that all the author's theology is rooted in this historical event. A closer study of DI seems to suggest Babylon as the place of composition only in orientation and not in setting (Motyer, 1999). Undoubtedly, mention is made of Babylon in the book but only on four occasions (Isa 43,14; 47,1; 48,14.20). There is no clear and convincing evidence that Isaiah ever lived in Babylon (Smart, 1965). A. Motyer (1999) contends too that the book is bereft of details proving an eye-witness account, such as the nature of the city, its structures and the societal organization of the exiles etc. In the places where the exiled are mentioned, they bear no relation to the homesick we see in Ps 137,1-6 (Motyer, 1999). The topological background of the place described in the book points more to Palestine than Babylon. For instance, we read of the idolater going into the wood to cut the tree for carving (Isa 46,14). However, we shall not over-burden ourselves with the place of the writing of DI. Its contents are our primary pre-occupation. 
Cyrus, the Persian, was raised up by God to be His servant (Isa 41,1-7). His task was to set Israel free from the shackles of Babylon. Israel and Judah have suffered exile and defeat. God has brought to actualization the curses of the Sinaitic covenant for their covenant-breaking idolatry (Deut 28,15-68). Yet, as sovereign God, He would still fulfil His covenant promises of ultimate blessings for His chosen despite their recalcitrance and refusal to participate in them. It is a period of divine visitation (Isa 52,3-6). Their yearning for Jerusalem (Psa 137) will come to fulfilment. God is to visit His people with peace. His visitation marked salvation for Israel. Isaiah proclaims this salvation to be a nucleus for world salvation. Israel was saved.

Cyrus, the pagan king, was a servant used to effect this divine plan. He was a SG to the extent that he was used to get God's purpose actualized (Isa 44,28). But the ultimate plan was the salvation of all (Isa 52,10). God's Servant would get this actualized. Over and above Cyrus, he would die for others. He would carry their burdens (Isa 53,4) and by his wounds all would be healed (Isa 53,5). Reading Isaiah, one sees a progressive shift from deliverance from Babylonian exile to final deliverance from worldwide dispersion by Yahweh's Servant-Messiah (Lindsay, 1985). This forms the bloc of the prophecy which authors technically describe as the Suffering Servant Songs These passages originally include Isa $42,1-4 ; 49,1-6 ; 50,4-9 ; 52,13-53,12$. It was the German scholar, Duhm (1892) who first isolated these passages. He said that they were written a century later than the author he called DI. Contrary to Duhm, however, scholars are in unanimous agreement that these passages form an integral part of their contexts (Zimmerli-Jeremias, 1995). Agreement is yet to be reached amongst scholars regarding the extent of each servant passage and the meaning, significance and overall contribution of 
each song (Rowley, 1952). Simian-Yofre (2005) sees Isa 42,1-7 as forming an unbreakable unit. He, therefore, limits the first Servant Songs (SS) to Isa 42,1-7. In our work, we have chosen to study the SS, limiting them to Isa $42,1-9 ; 49,1-6 ; 50,4-9 ; 52,13-53,12$.

\section{The Literary Context of DI}

Generally Isaiah 1-39, otherwise called FI, is centred on God's judgement. It speaks in part of the ultimate restoration of creation by God through His judgement. Martin - Martin (1983) describes it as "salvation of Yahweh through His Servant to the ends of the earth". In as much as we do not intend to undermine the homogeneity of Isa 1-39, it is good to observe some salient aspects within this whole bloc of FI. For example, Isa 9 and 11 are prophetic texts about the Messiah. Isa 24-37 could be said to be apocalypse of Isaiah while Isa 38 deals with the prayer of Hezekiah. These observations do not cancel the traditional division but they are conspicuous to be neglected.

Isa 40-55, constitute the DI. It is within this bloc that we have the SS. The SS dwell primarily on the Suffering SG. They contribute largely to the unity of the entire DI by laying emphasis on the Servant's ultimate accomplishment of his mission. Apart from restoring Israel to the land (Isa 49,8-12), the establishment of justice on the whole earth is his primary Herculean task (Isa $42,1.3 .4 ; 49,6)$. In FI, this future salvation of all is also portrayed with some prominence (Isa 7-12; 25-27). In Isa 40-66, God still reveals this primary purpose of salvation for His people both in the immediate future, i.e. the Cyrus oracle (Isa 45), and also in the remote future as seen in the SS. Thus in its remote context, the parts of the book of Isaiah are interwoven and express some thematic unity. 
In its proximate context, the SS manifest some thematic distinctiveness in focusing on an individual servant. This individual servant is distinguished from the national servant seen in the surrounding chapters.

\section{Message}

The book of Isaiah in general could be said to be a synthesis of OT theology. His message appears in three moments, viz., God, Eschatology and Messiah. Like most OT books, he sets God forth as the King of Israel (1Sam 12,12; Pss 93; 95-99; Isa 33,22; 43,15; Ezek 20,33). He is the initiator of both judgement and restoration of Israel. Isaiah is very technical and selective in his words. For example, he uses the term Yahweh more preponderantly than Elohim/El. This is because, theologically, the former gives a better picture of God as a judge and restorer addressing and centring on his covenant people. Smick (1965) tied this term to its root to mean "to be" or "to become".

Freedman (1986) describes it as Tetragrammaton and personal name of the God of Moses. He traces it to the root $h w y$ or hyh meaning "be at hand, exist, come to pass". The latter expresses God as sovereign ruler and controller of creation and history. Smick (1965) defines Elohim to mean "mighty" or "strong". From its root, it means the mighty one. In the OT, it is used interchangeably with 'el and 'eloah (cf. Gen 6,2; Job 1,6; Ps 29,1 and 89,6). Ringgren (1986) presents Aramaic 'alah and Arabic 'ilāh as possible cognates. He also sees 'elohim as a possible plural form of 'el from the root 'wl. According to him, the original meaning is "might or power". Isaiah both explicitly (Isa 6,5; $33,17.22 ; 41,21 ; 43,15 ; 44,6 ; 24,23 ; 52,7)$ and implicitly presents God as both King and Ruler. Isaiah has a lot of motifs depicting God as King. One example is the Royal Shepherd motif of Isa 
40,11; 49,8-10. Mendenhall (1954) and Kitchen (1978) also talk of the Suzerain-Vassal motif. Covenant lawsuit of Yahweh is another motif found in Isaiah picturing God as being in control (Gemser, 1955; McCarthy, 1972). God is also presented as a warrior (Miller, 1973). God's regal authority is also seen in His actions of purposing (Isa 14,24.27; 46,10), speaking (Isa 9,8; 31,2; 40,8; 45,$23 ; 55,10-11$ ), judging and blessing (Isa 1,$25 ; 9,11 ; 10,4 ; 40,2$; $41,20 ; 43,13 ; 51,5.9 ; 59,16 ; 60,21)$.

Isaiah in his eschatology establishes God as the incomparable and holy one. He presents Him as one who through judgement, deliverance and restoration seeks to establish His Kingdom on earth. He is in control of history. He judged Israel to purge them of idolatry and so produce righteousness (Isa 1,26; 4,4; $32,15-20 ; 40,2)$. Similarly, God is to judge the world for its evil, especially for rebellion against Him (Isa 13,11). His ultimate purpose is to glorify himself (Isa 33,10; 45,6; 66,18-19). Looking at the chronology of judgement, one sees a principle of progressive fulfilment. Some judgements were fulfilled at the Babylonian and Assyrian captivities. Others await the end-time fulfilment (Isa $13,9-13$; 34,8-10).

Isaiah 40-66 (DI and TI) presents an eschatology a little more developed than what we have in FI. It emphasizes the restoration of all things to the divine ideal. But this time it is a restorative act limited to a remnant who would survive the eternal judgement on the wicked and so enter into the blessings of the messianic kingdom (1985). Unlike FI, the author limits the instruments at God's hand in realization of this salvation to the twin themes of Davidic Messiah and the SG (Isa 53,12) and in the concepts of the Word (Isa 45,14.22-25; 55,10-13). He delivers because $\mathrm{He}$ is faithful to His covenant with Abraham, David and the new covenants. For Isaiah, restoration of the whole earth will 
be characterized by an experience of paradisiacal conditions. The curse of Eden will be removed (Isa 51,3) and nature transformed (Isa 41,17-20; 51,3; 55,13). Animals will be tamed (Isa 43,20; $65,25)$ and peace and justice will prevail. Isaiah presents a case of God's plan to actualize His will and righteousness on earth through chosen instruments. These instruments, especially kings, reflect an ideal Messiah who is to come (Lindsey, 1985). Isaiah does not deviate much from other OT prophecies of a coming mediatorial deliverer. We include here, such prophetic passages as the Prophet like Moses (Deut 18,15-19; cf. John 5,45-47; Acts 3,22-23; 7,37); the branch (Jer 23,5; 33,15; Zech 3,8; 6,12); the Son of Man (Dan 7,13-14); Yahweh himself as deliverer (Ezek 34,11-12; Hos 3,5; Joel 3,16-17; Amos 1,2; Mal 3,1).

To be included here is the dynastic promise to David in 2Sam 7,11-16. In many respects, his prophecy is the high-water mark of messianic prophecy. The qualities of this ideal Messiah he presents in his SS. This Servant for him is a royal figure chosen by God and endowed with His Spirit (Isa 42,1-2). He is to bring salvation and to effect proper order on the whole earth. Isaiah's emphasis on the SS is on the introduction of the Servant and his completion of the task. Payne (1979) observes that the language of Isaiah's SS seems to link kingly and prophetic characteristics in a role reminiscent of that of Moses. He believes that it is as if to say that in this second exodus, namely, the deliverance of Israel and eventually, of the whole world, a second Moses is required.

\section{The Concept of SG and Isaiah's connection}

In the OT, the term 'SG' applies to individuals. In 2Sam 3,18, it refers to David. Ezek 34,23-24 calls him the Messianic David. Hag 2,23 has Zerubbabel. For Jer 27,6, Nebuchadnezzar is SG. From the Jewish understanding of Servant, the term connotes a 
mission. The Hebrew term for servant is $\mathrm{db}$ [. On its own, it could refer to a slave (Exod 21,20-21). It can also be used in reference to a vassal king (2Sam 10,19), an individual subject (Gen 21,25) or a tributary nation (1Chr 18,2.6.13). The term expresses dependence and servitude. With the addition of the appellation 'God', the term transcends the derogatory aura of mere servitude to denote the highest honour (Lindsey, 1985). It involves a duty in relation to God. This is why it is often connected with both the king and the prophet. Cyrus of Persia is God's Servant in his mission to save the Israelites (Knight, 1984) though he was not an Israelite himself. Even Nebuchadnezzar is called God's servant in Jer 43,10. David is given the same name in Ps 36,1. Jacob, too, is called the SG in Ezek 28,25. In Dan 6,20 and 9,17, Daniel is described as Servant of the living God. Moses, the popular Israelite leader, is in several places presented as SG (Josh 1,13.15; 22,4.5; 2Kgs 18,12; 1Chr 6,49; 2Chr 24,9; Neh 10,29; Dan 9,11). Israel is also called God's servant in her mission as described in Isa 41,8; 42,19; 44,1; 44,21; 45,$4 ; 48,20$ and specifically in Isa 49,3.

Israel is not referred to as servant in the sense of historical Israel but in the sense of mission. Lindblom (1951) contends that the SG is not a historical individual nor a mythological figure. For him, he is a Messiah yet to appear, a soteriological rather than political figure. Also Knight (1965) has the same line of thought. He maintains that God chose Israel not to be served but to serve. Of herself, Israel is nothing. She is only a vehicle of mission, to bring the true way of life to the masses of humanity who are longing for revelation (Isa 42,1-4). In Isaiah, especially in DeuteroIsaiah, it goes beyond the prophet and the king. Outside the SS, DI on many occasions calls Israel the SG (Isa 41,8f; 44,1.21; 45,4; $48,20)$. In the SS, anonymity beclouds the identity of this SG. An exception is probably Isa 49,3. In this verse, Isaiah calls Israel the 
SG. We would like to observe that even here the identity of the Servant may not really be Israel, contrary to what most translators believe. This is because one may take the 'Israel' in Isa 49,3 to be in the vocative case. Taken this way it would mean that the Servant refers to Israel and to no other. One can also take it as an extension of the predicate 'servant'. True, outside the SS, Israel is sometimes called the SG. But to transpose a similar reference into the understanding of the SS is problematic. This is not just because of the fact that in other parts of the SS the Servant is anonymous, but more because in Isa 49,5 the Servant of Isa 49,3 has a mission to Israel.

It follows most likely that the Servant in Isa 49,3 cannot actually be Israel as a nation. This is because Israel cannot be sent on a mission to the same Israel. M. Rosen (1982) agrees that “... since we read ... that the Servant's mission is primarily Israel, it must refer to some individual who incorporates the nation of Israel as a king might be said to embody his people" (p. 59). Even if we take God to be the one effecting the mission of gathering Israel to Himself in Isa 49,5, we still face the difficulty that in other passages in which Israel is addressed as servant, Jacob-Israel is called by name in the third person (1966). It is our position, therefore, that the anonymity of the Servant read in other parts of the SS extends even to Isa 49,3. The Servant is not mentioned by name. His work is obvious. It is mission oriented. It is salvation for Israel and then also for the whole world.

The work of this anonymous Servant has its climax in his giving up of himself willingly as a sin offering for others. He heals others through his innocent suffering. He brings judgement and righteousness through his death and not via conquests and then enters into glory (Dodd, 1971). 


\section{The SG Passages, their Contexts and Characteristic Attributes of the SG}

Some scholars do not accept the traditional isolation of the SS from the rest of DI. Snaith (1945) for instance argues for the holistic nature of the DI oracles. He does not see sufficient reason for isolation of the SS. He contends that there are some passages in DI that are not included in the SS but bear remarkable similarity with the SS. He cites Isa 51,4-6 as an example. He maintains that there is similarity of content between this passage and Isa 42,1-4 even though it does not mention anything about the Servant. He concludes that the Servant of the SS is the Servant of the rest of the oracle, and so no chapter is to be isolated. Such arguments fall outside of the purview of our exercise. We would however, want to note that we accommodate, at least in principle and extension, the traditional division. This is essentially because it forms the section that really expresses the theme - SG - the concern of this paper. They are the four chapters that most explicitly speak about the mission of the Servant.

This research is not geared towards a full exegesis of all the SS passages. It is therefore necessary to have a global view of what each of the SS is all about. In other words, a summary of the contents of each passage and its message is needed. This is the major pre-occupation of this section. It is designed to give a global view of the contents of each of the SS passages. It is not necessarily an interpretation. It is more a literal presentation of the content of each passage. It is essential because it will give a stronger footing to understand the structural design of the prophecies as well as the interpretation of the qualities of the Servant as pictured by Isaiah. The first section covers the contents of each passage. The second part deals with the attributes of the SG. 


\section{The SS Passages and their Contexts}

In our work, we have included as the SS Isa 42,1-9; 49,1-6; 50,4-9 and Isa 52,13-53,12. Most scholars limit the first SS to Isa 42,1-4. North (1948), for example, calls only Isa 42,1-4 the first SS. He does not see it as extending beyond these verses. We have extended it to include vv. 5-9 also. Many scholars accept this extension too. Koole, 1998; Hooker, 1959; Motyer, 1999. Our extension is substantiated by the fact that the demonstrative adverb, hKo, which marks the beginning of the next verse, indicates both a linkage with what precedes and a continuation of the speech. Thus v. 6 continues the address to the Servant regarding his vocation and tasks. Vv. 8-9 do not show any breakage. The speaker is still the same subject, God. The one spoken to is still the Servant. The language of the commissioning of vv. $5 \mathrm{ff}$ has an indubitable reference to the Servant of vv. 1-4. Contextually, therefore, one can say that these passages supplement each other (2001). The link is broken as soon as one gets into v. 10.

The content of this first SS is straightforward. In it, God chooses His Servant to bring justice to the nations. He is to bring freedom to the enslaved and sight to the blind. His vocation is from God the creator, a jealous God who does not share His glory with another one. He is God's elect and is upheld by Him. The Spirit of God rests on him. He is charged to bring judgement on earth. His method is one of quiet patience and non-violence yet without failure until he accomplishes God's given task. Rosen (1982) describes him as unassuming character. Scholars are not agreed as to the identity of the Servant referred to here. North (1948) talks of supra-mundane beings. Kaiser (1979) in the same line of understanding calls the addressee, the heavenly court. Lindblom (1951) understands the prophet himself as the addressee. One can 
think of the connection between the passage and the one preceding it, Isa 41,8-20, where Israel is overtly addressed as the Servant. Two outstanding problems challenge the validity of this interpretation. In Isa 41,21-29, the address gradually and finally shifts to the nations and their gods. Also the first word used in our text is important for the understanding of the identity of the Servant addressed. The $\mathrm{h}$, is a demonstrative interjection, which calls attention to a fact upon which action is to be taken or a conclusion based. Koehler and Baumgartner (1998) interpret it to mean 'behold', pointing to the word which it precedes and to a noun which is then defined.

Our text actually refers to an unidentified Servant. It is talking about a Servant. The subject of attention is a particular Servant. But the identity is beclouded and obscure. Looking at ih strictly, we can say that it functions in the text as the subject of a nominal clause (here is/there is) with a predicate introduced by $\mathrm{db}$ [ (servant). Isa 23,13 and 40,15 have a similar application (Clines, 1993). The text does not indicate that the Servant is coming. He is rather presented as a figure whose surprising appearance invites the greatest attention. Were the reference to be connected to Isa 41,8 , then this special introduction would be uncalled for (Koole, 1998). Again, Isa 41,8 , as well as Isa $44,1.21 ; 45,4 ; 48,20$, identify the $\mathrm{db}$ [ as Jacob-Israel, while anonymity covers the $\mathrm{db}$ [ in the SS, except in Isa 49,3 which we have explained already. On the basis of these explanations, we maintain that the SG addressed in Isa 42,1-9 is unknown, just as he remains in the other SS - Isa 49,16; Isa 50,4-9 and Isa 52,13-53,1-12.

This periscope very well outlines the task of the Servant namely, to establish judgement on the nations. Verse 1 identifies God as the source of all that the Servant is and is called to do. The Servant is never left on his own, for God has put His Spirit upon him. After 
identifying God as the primary source of all for the Servant, the section continues to name the task of the Servant and the manner in which God expects him to effect the task. God then gives him an assurance of His unflinching support and then designates him as a covenant to the people and a light to the nations (v. 6b). The next verses give specificity to the implications of the covenant as it reaches the nations.

Isa 49,1-6 is the second SS. Already Isa 42,1-9 speaks about the Servant. Isa 42,5ff, attributes its speech to the servant. Then, after the preparation of Isa 48,16b, the Servant now talks himself in Isa 49,1-6. The song introduces the theme of opposition to the Servant (Isa 49,4.7). It presents the Servant as chosen by God for His glory. He is called right from his mother's womb. He has a universal task. He is to restore Israel and bring salvation to the nations. This he will fulfil by addressing the nations, promising worldwide salvation (v. 6b).

yl;ae yYlai W[m.vi (Listen to me O coastlands!) bears an air of authority and self-confidence. The verb $W[\mathrm{~m} . \mathrm{vi}$ is qal imperative. The Servant calls for attention not with an appeal but with authority and power. But in a world dominated by Nebucchadnezzars and Pharaohs, one wonders about the foundation of the confidence of this Servant. The construction only indicates that the legitimacy of the Servant has divine origin.

In v. $1 b$, he points to God as the source of his vocation. Hence the legitimation to speak with authority. Just as in John 3,11, he speaks of what he knows. God chose Israel for His glory. He protected her as His own to obey and testify. Till now, this purpose of God is a defeated and breached one. A new Servant must arise. He is to be Servant pro-Deo (v. 3), just for the sake of God's honour and glory. He is the true Servant through whom the people will testify and proclaim God's saving justice. 
In v. 3, the Servant identifies himself as Israel. Surely, it is not the fallen Israel. He is the ideal Israel, fulfilling in himself what the Israelites neglected. He does not want to be isolated from the community of Israel. In Isa 49,5, he demonstrates a very special relationship with Israel.

Like the prophets and servants of God before him, he narrates his disappointment with Israel. He sees his work with Israel as foundered. He tells us in vv. 4a.5a.6a about the crisis period in his life: he toiled in vain, he spent his strength for nothing, but, with confidence, he is certain that his recompense is with God. Verses 5.6 give details of God's new task for the Servant to the nations. God's Spirit is his power (Isa 42,1; 48,16). The entire world is his field of work. Thus, in this new Servant, both Israel and all other nations are given perspective. He is the Light of the World (Isa 42,6; John 1,11-18). Isa 50,4-9 contains a bloc of monologue by the Servant. Authors like Wolf (1985) extends this third SS to v.11. This paper is limiting it to Isa 50,4-9 because, while the latter has the Servant as the speaker, v.10 further on seems to have another speaker. This is clear from ADb.[; of v.10 and ydlY"mi of v.11. Contextually, it continues the flow of thought in Isaiah's picture of the SG. The mission of the Servant is to be costly and will involve him in suffering. Already in Isa 42,19, God spoke about and to His Servant.

In Isa 48,16, the Servant presented himself, and in Isa 49,112 he points out his task to Israel and other nations. The people and Zion are to be restored. In Isa 50,1-2, the Lord uses rhetorical questions to denounce people who blame their woes on their mother and so offset the grandeur of Isa 49 . Isa 49 is clearly addressed to Israel and Zion. Isa 50 contains no proper names. The Servant is the speaker in Isa 50,4-9. Every part of the monologue begins with 'the Lord Yahweh', indicating that God is present in 
every part of the Servant's Mission. This idea is also true of the gospel of John. In John 16,32, Jesus makes it clear that he would not be left alone because the Father is always with him. The secret of the Servant's comfort, independence and trust, even in the midst of his sufferings, is founded on this divine name. God is the one who gives him what to say (Isa 50,4), opens his ear (Isa 50,5) and helps him (Isa 50,7). In all, God is his invisible source of power.

In v. 4, he calls himself God's disciple. He confesses that his tongue is a gift from God and that, with confidence, he says what he heard. This same idea prevails in the Gospel of John. Cf. John 3,32;8,26; 14,24. In vv. 5-6 he recalls his sufferings. He is a man of sorrows. He was not taken seriously, yet he remains obedient. He suffered willingly. These verses contain a number of verbs carefully chosen to convey the idea of shame, disgrace, insult and humiliation (Miscall, 1993). Despite all these, his trust in God does not waver. He still has confidence in God's help (Isa 50,5-7).

In Isa 52,13-53,12, the author begins with an enigma. The Servant goes from obscurity and denigration to prominence and vindication. Exaltation arises out of suffering, and the suffering leads to universal benefit and acknowledgement (Isa 52,13-15). This enigma is resolved in Isa 53,10-12 where the text explains the Servant's suffering as a bearing of sin. This image accords well with the transformation sketched for Jerusalem in Isa 51,17-52,12. It also agrees with the image of the woman in Isa 54. The Lord calls attention to his Servant who is wise and prosperous. The oracle commences with hNEïhi, a particle inviting attention. Similar usage is found in Isa 41,20 and 44,18. Hanson (1998) describes the fourth SS as part of Isaiah's depiction of the new way that God was opening for Israel after the failure of the old way which was intended to lead them to their destiny as witnesses of divine volition and salvation to the nations. This fourth SS is made 
up of four stanzas, each containing three verses. The opening stanza, Isa 52,13-15, gives a description of both the suffering and exaltation of the Servant. In vv. 14-15, in particular, a distinction is made between a past of humiliation and a present and future of wonder and between nations and kings. Without any precise chronology, the text states that many nations are startled and shocked into silence. The text draws on Isaiah's comments on the relationships between appearance and reality, true and false, hearing-seeing and understanding-knowing (Cf. also Isa 5,18$19.20-22 ; 6,9-10 ; 26,7-12 ; 41,20 ; 43,8-10 ; 45,1-6 ; 48,1-8)$. The Servant appears to be nothing but is, in reality, wondrous. He is not desired while idols are delighted in (Isa 44,9). He is thought of as afflicted (Isa 51,21), but actually he is bearing our iniquities (Isa $53,4)$.

The second stanza comprises Isa 53,1-6. We can subdivide it into two parts. Isa 53,1-3, emphasizes on the lowliness and rejection of the Servant. In Isa 53,4-6, the vicarious death of the Servant is dealt with. He is presented as dying for the sins of mankind. Wolf (1985) explains the Servant in this verse as the substitute who bore the sins of many. The third stanza, Isa 53,7-9, discusses how the Servant suffered, died and was buried. In the concluding stanza, Isa 53,10-12, the theme of exaltation begun in the first stanza, Isa 52,13-15, is revisited. The work of the Servant is portrayed as a great victory. An apparently pitiful display of weakness ended as a victory of massive proportions.

It is impossible to bring out the wealth of ideas in these great passages here. We reserve it for our future studies. It is, however, pertinent to observe that the four SS are not unconnected. They are bound together by a string of striking connections. The Servant in Isa 49,1-6 and Isa 50,4-9 is introduced by the divine word of Isa 42,1-9. The Servant speaks, and now again God is the 
speaker. The wheel of the rhetoric comes full circle because in the task assigned to the Servant in Isa 42,1-9 he did not fail, despite Isa 49,4. The glory promised him did not end in catastrophe despite Isa 50,6 but is recognized. His humiliation turned out to be the gold thread of his exaltation (Koole, 1998). The Servant is elevated; the mood changes. Everything becomes different. The negative attitude of dismay turns into a positive one of speechlessness. The reaction is worldwide. In his suffering only Israel was a close witness, but in his exaltation, kings and peoples pay tribute to him (Isa 49,7), and so he becomes light to the nations with the light shining everywhere (Isa 42,6; 49,6). All the other SS already predict the elevation of this humiliated SG (Isa 42,1-9; 49,1-6; 50,4-9).

\section{Evaluation and Conclusion}

This research is not head bent on revealing the identity of the Servant of God. It points out selflessness as the distinguishing character of this Servant of God. His selflessness is manifest in his humility and silent obedience marking him out light to the nations. It is because of the same virtue that he died for the sake of others forming the gold thread of his exaltation such that kings stood speechless. Nigeria is today talking of economic recession. A country that was classified as the richest in Africa just last year got shaded within a year. Corruption is always mentioned as the remote cause of the Nigerian problem. The issue is that Nigeria is not and can never be corrupt. Individuals in Nigeria are the corrupt agents and also sufferers of the effect.

The situation of Israel was not less as at the time Isaiah envisioned his suffering servant. Chinua Achebe rightly pointed out leadership as the trouble with Nigeria. The researcher wants to add that it is no longer only leadership. The trouble with Nigeria is 
Nigerians themselves. Corruption has gone into every fabric of the Nigerian structure. In fact, not to be corrupt sounds strange to average Nigerian. Every sector is corrupt. The mentality is always "what will I gain" and not "what will I give". Every individual considers what Nigeria will do for him and not what he will do for Nigeria. It is really unfortunate. The researcher is convinced that until the altruism, humility and obedience of the SG is imbibed by Nigerians especially the leaders, our economy will not only recess but will get depressed soon.

\section{Dominic C. Obielosi}

Department of Religion and Human Relations

Nnamdi Azikiwe University, Awka dobielosi@yahoo.com

\section{References}

Childs, B.S. (2001). Isaiah. Louisville: John Knox Press.

Clines, D.J.A. (1993). The Dictionary of Classical Hebrew I-II. Sheffield: Phoenix Press.

Dodd, C.H. (1971). The Old Testament in the New. FBBS I-IV, Philadelphia: Athlone Press.

Duhm, B (1892). Das Buch Jesaia, Übersetzt und erklärt. Göttingen: Mohr Press.

Eissfeldt, O. (1965). The Old Testament. An Introduction, P.R. Ackroyd trans. London: Fortress Press.

ferreira, J. (1998). Johannine Ecclesiology, JSNT.S 160. Wales: Sage Publishers. 
Freedman, D.N. \& O'Oconnor, M.P. (1986). "hwhyYHWH", Theological Dictionary of the Old Testament, V. Chicago: Wm. B. Eerdmans Publishing Co. Pp. 500-521.

Gemser, B. (1955). "The Rib or Controversy-Pattern in Hebrew Mentality", VT.S 3 Leiden pp. 120-137.

Gray, G.B. (1912). The Book of Isaiah I-II, ICC. New York: C. Scribners Sons.

Hanson, P.D. (1998). "The World of the Servant of the Lord in Isaiah 40-55", W.H. Bellinger and W.R. Farmer eds. Jesus and the Suffering Servant. Isa 53 and Christian Origins. Harrigburg: Trinity Press.

Harrison, R.K. (1969). Introduction to the Old Testament. Grand Rapids: Hendrickson Publishers.

Archer, G.L. Jr. (1964). A Survey of the Old Testament Introduction. Chicago: Moody Press.

Hooker, M.D. (1959). Jesus and the Servant. The Influence of the Servant Concept of Deutero- Isaiah in the New Testament. London: Wipf and Stock Publishers.

Kaiser, O. Der Königliche Knecht. Eine Traditionsgeschichtlichexegetische Studie über die Ebed-Jahwe Lieder bei Deuterojesaja. FRLANT 70. Göttingen: Vandenhoeck and Ruprecht.

Kitchen, K.A. (1978). The Bible in its World. Downers Grove: Paternoster Press.

Knight, G.A.F. (1965). Deutero-Isaiah. A Theological Commentary on Isaiah 40-55. Nashville: Abingdon Press.

Koehler, L. \& Baumgartner, W. (1994). The Hebrew and Aramaic Lexicon of the Old Testament. Boston: Brill Academic Publishers.

Koole, J.L. (1998). Isaiah I, HCOT I-III. Leuven. 
Lindblom, J. (1951). The Servant Songs in Deutero-Isaiah. A New Attempt to solve an Old Problem. Lund: C.W.K. Gleerup.

Lindsey, F.D. (1985). The Servant Song. A Study in Isaiah. Chicago: Moody Press.

Martin, A. \& Martin, J.A. (1983). Isaiah. The Glory of the Messiah. Chicago: Moody Press.

McCarthy, D.J. (1972). Old Testament Covenant. A Survey of Current Opinion. Atlanta: John Knox Press.

Mckenzie, J.L. (1965). Dictionary of the Bible. New York: Bruce Publishing Company.

Mendenhall, G.T. (1954). "Covenant Forms in Israelite Tradition", BA 17 (1954) pp.24-46.

Miscall, P.D. (1993). Isaiah. Readings. England: Intervacity Press. Morgenstein, J. (1961). The Message of Deutero-Isaiah in Its Sequential Unfolding. Cincinnati: Hebrew Union College Press.

Motyer, A. (1999) Isaiah. Tyndale Old Testament Commentary. England: IVP Academy.

North, C.R. (1966). Isaiah 40-55. The Suffering Servant of God. London: SCM Press.

Payne, D.F. (1979). "Isaiah", G.C.D. Howley et al. Grand Rapids.

Ringgren, H. (1986). "'ayhiOla? 'elohim", Theological Dictionary of the Old Testament, V. Chicago: Wm. B. Eerdmans Publishing Co. Pp.267-284.

Rosen, M. (1982). Y'shua. The Jewish Way to Jesus. Chicago: Moody Press.

Rowley, H.H. (1952). The Servant of the Lord and Other Essays on the Old Testament. Oxford: Blackwell Publishers.

Simian-Yofre, H. (2005). Sofferenza dell'Uomo e Silenzio di dio nell'Antico Tetament e nella Letterautra del Vicino Oriente Antico. Roma: Citta Nuova. 
Smart, J.D. (1965). History and Theology in Second Isaiah. Epworth: Westminster Press.

Smick E.B. (1925). "Elohim", ZPEC

Smick, E.B. (1925). "Yahweh", ZPEC V.

Snaith, N.H. (1945). “The So-called Servant Songs”, ET 56 (1945) 79-81.

Wolf, H.M. (1985). Interpreting Isaiah. The Suffering and Glory of the Messiah. Grand Rapids: Zondervan Publishers

Zimmerli, W. \& Jeremias, J. (1984). "pai/j qeou/". Theological Dictionary of the New Testament. Chicago: Wm. B. Eerdmans Publishing Co. Pp. 654-717. 